\title{
DEFINITION OF THE PATENT AND THE PERIOD OF PROTECTION
}

\author{
Arga Ade Audiya \\ 175100064P \\ Faculty of Computer, 448757149 \\ Argaadeaudiya.student@umitra.ac.id
}

\begin{abstract}
Patent is a special right granted by the State to the inventor for the results of his invention in the field of technology, for a certain period of time implementing the invention himself or giving his approval to others to carry it out, types of patents namely patents and simple patents. Patents are exclusive rights granted by the state to inventors for the results of their inventions in the field of technology which for a certain period of time carry out their own or give approval to other parties to implement them while Simple Patents are any inventions in the form of new products or tools and practical utility the form, configuration, construction, or component can obtain legal protection in the form of a simple patent

Patent Protection Period As known in Article 8 paragraph 1 of Law No. 14 of 2001 concerning Patents, the patent is granted for a period of 20 (twenty years) from the date of receipt and the period cannot be extended, whereas for a simple patent given for a period of 10 (ten years) from the date of receipt and the period cannot be extended. If the patent protection period has expired, an event will become a public domain so that other parties can freely produce and sell it. The rules regarding the validity period of the patent are intended so that no party can continuously control the entire industry so that it is feared that it can harm the community and the trading system.
\end{abstract}

Keywords: Types of patents, time period 


\section{A. INTRODUCTION}

Patent is a special right granted by the State to the Inventor for the results of his invention in the field of technology, for a certain period of time implementing the invention himself or giving his consent to others to implement it (Article 1 paragraph 1 of the Law on Patents).

And, based on Article 1 paragraph 2 of Law Number 14 Year 2001 states that, "invention is an inventor's idea that is poured into a specific problem-solving activity in the field of technology can be a product or process or a product or process improvement and development."

Based on the meaning of the invention, it can be seen that the characteristic that can be patented is a systematic content that can be communicated applied to solve human problems or needs that arise in industry, agriculture, or trade.

\section{Types of Patents}

In Law Number 14 of 2001, patents can be divided into 2 (two) types, namely:

1. Patent is an exclusive right granted by the state to the inventor for the results of his invention in the field of technology which for a certain period of time implements himself or gives approval to other parties to implement it (Article 1 number 1 of Act Number 14 of 2001); and

2. A Simple Patent is any invention in the form of a new product or tool and has practical utility value due to its shape, configuration, construction, or component, which can obtain legal protection in the form of a simple patent (Article 6 of Act No. 14 of 2001).

Between the two types of patents have several differences including:

If, Patent:

1. Complex technology;

2. Product and process inventions;

3. Material requirements that must be new, there are inventive steps and applied in the industry and not including inventions in Article 7;

4. The substantive examination is said to have passed, if the invention complies with Article 2 ,

3, 5, 7 UUP;

5. To conduct a substantive examination must submit a request for substantive examination; 


\section{QUIZ Selected Section Class}

6. A compulsory license can be requested;

7. Protection period of 20 years from the date of receipt.

Whereas Simple Patents:

1. Simpler technology
emphasizes
functions;

2. Products / visible products (products);

3. Simple patent material conditions are new and can be applied in industry;

4. Substantive examination only covers the value of renewal and can be applied in industry;

5. To carry out a substantive examination, it can be done simultaneously with the submission of the application or at the latest 6 months from the date of receipt;

6. A compulsory license cannot be requested; and

7. The tenure of 10 years from the date of receipt.

\section{Patent Protection Period}

As known in Article 8 paragraph 1 of Law No. 14 of 2001 concerning Patents, the patent is granted for a period of 20 (twenty years) from the date of receipt and the period cannot be extended, whereas for a simple patent it is given for a period of 10 (Ten years) from the date of receipt and the period cannot be extended,
If the patent protection period has ended, an event will become a public domain so that other parties can produce and sell it freely. The rules regarding the validity period of the patent are intended so that no party can continuously control the entire industry so that it is feared that it can harm the community and the trading system.

3. Definition of Inventor and Patent Holder

Inventor is the inventor or one of the subject of patents, in this case, which can be used as an inventor of only people, either individuals or more than people, namely together. In the law the definition of an inventor is a person who or some person who jointly implements the ideas poured into activities that produce inventions.

On the other hand it is also known that there are rights holders, namely the patent holder is the inventor as the patent owner or the party who receives further rights, which is registered in the general list of patents.

In reality inventors do not have the ability to carry out patents or find an invention considering the need for costs that are not small in carrying out patents or research to produce an invention, so to anticipate this the law provides 
a way out in the form of patent transfer.

4. Subject of Patent and Patent Object (Process Patent and Product Patent)

Discussing the provisions of a patent subject means reviewing inventors who are inventors or one of the subject of patents, in this case those who can be used as inventors are only people, individuals or more than people, namely together. In the law the definition of an inventor is a person who or some person who jointly implements the ideas poured into activities that produce inventions.

On the other hand it is also known that there are rights holders, namely the patent holder is the inventor as the patent owner or the party who receives further rights, which is registered in the general list of patents.

While the so-called object patent consists of two types, namely process patents and product patents. Process patents are claims to processes from inventions made by inventor. Patent process includes process or use. For example, the process of making ink, and so on. Whereas, production patents are claims against inventions in the form of products made by inventor. Product patents include tools, machines, compositions, product formulations for processes, systems, etc. For example, stationery erasers, drug compositions, and so on.

5. Rights and Obligations of Patent Rights Holders

Patent and inventor rights holders still have the right to exploit their patents, in addition to having moral rights that remain inherent in inventor. The rights of patent holders include:

1. Moral rights, namely the transfer of rights does not erase the right of the inventor to keep the name and identity included in the relevant patent (Article 68);

2. Economic rights, namely inventors still obtain economic rights (economic benefits) in return. These benefits are known as royalties (Article 12 paragraph 3 and 4);

3. Right holders have exclusive rights to carry out patents held and prohibit other parties without consent, for example making, using and selling (Article 16 paragraph $1)$;

4. Transfer rights and give their rights (Article 16 paragraph 1).

On the other hand, rights holders still have their obligations, namely: 


\section{QUIZ Selected Section Class}

1. Based on Article 17 states that, "without prejudice to the provisions of Article 16 paragraph 1, the patent holder is obliged to implement the product or use a process that is granted a patent in Indonesia." 2. Under Article 18 states that, "patent holders or licensees are required to pay an annual fee to manage the continued validity of patents and registration of licenses."

\section{B. CONCLUSION}

Patent is a special right granted by the State to the Inventor for the results of his invention in the field of technology, for a certain period of time implementing the invention himself or giving his consent to others to implement it (Article 1 paragraph 1 of the Law on Patents).

In Law No. 14 of 2001, patents can be divided into 2 (two) types, namely simple patents and patents

As known in Article 8 paragraph 1 of Law No. 14 of 2001 concerning Patents, the patent is granted for a period of 20 (twenty years) from the date of receipt and the period cannot be extended, whereas for a simple patent it is given for a period of 10 (Ten years) from the date of receipt and the period cannot be extended,
If the patent protection period has ended, an event will become a public domain so that other parties can produce and sell it freely. The rules regarding the validity period of the patent are intended so that no party can continuously control the entire industry so that it is feared that it can harm the community and the trading system.

\section{ACKNOWLEDGEMENT}

University Of Indonesia

University Of Mitra Indonesia

Telkom University

University Of Mellbourne

Saitama University

\section{REFERENCE(Based ISO 690 )}

[1] A. S. Putra And O. M. Febriani, "Knowledge Management Online Application In Pdam Lampung Province," In Prosiding International Conference On Information Technology And Business (Icitb), 2018, Pp. 181-187.

[2] A. S. Putra, O. M. Febriani, And B. Bachry, "Implementasi Genetic Fuzzy System Untuk Mengidentifikasi Hasil Curian Kendaraan Bermotor Di Polda Lampung," J. Sist. Inf. Dan Manaj. Basis Data, Vol. 1, No. 1, Pp. 21-30, 2018.

[3] O. M. Febriani And A. S. Putra, "Sistem Informasi Monitoring Inventori Barang Pada Balai Riset Standardisasi Industri Bandar Lampung," J. Inform., 
Vol. 13, No. 1, Pp. 90-98, 2014. Putra, Arie Setya. "2018 Artikel Struktur Data, Audit Dan Jaringan Komputer." (2018).

[5] Putra, A. S. (2018, July 17). Paperplain Fundamental Create Application With Borland Delphi 7.0 University Of Mitra Indonesia. Retrieved From Osf.Io/Pbrn9.

\section{E. REFERENCE(Based APA )}

Putra, A. S., Aryanti, D. R., \& Hartati, I. (2018, November). Metode SAW (Simple Additive Weighting) sebagai Sistem Pendukung Keputusan Guru Berprestasi (Studi Kasus: SMK Global Surya). In Prosiding Seminar Nasional Darmajaya (Vol. 1, No. 1, pp. 85-97).

Sari, D. P., Febriani, O. M., \& Putra, A. S. (2018, November). Perancangan Sistem Informasi SDM Berprestasi pada SD Global Surya. In Prosiding Seminar Nasional Darmajaya (Vol. 1, No. 1, pp. 289-294).

Putra, A. S. (2018). Paperplain: Execution Fundamental Create Application With Borland Delphi 7.0 University Of Mitra Indonesia.

Putra, A. S., Sukri, H., \& Zuhri, K. Sistem Monitoring Realtime Jaringan Irigasi Desa (JIDES) Dengan Konsep Jaringan Sensor Nirkabel. IJEIS (Indonesian Journal of Electronics and Instrumentation Systems), 8(2), 221232.

Darmawan, A., Yuliawati, D., Marcella, O., \& Firmandala, R. (2016). Sistem Absensi dan Pelaporan
Berbasis Fingerprint dan SMS Gateway. EXPLORE, 7(1).

Febriani, O. M., Wahyuni, T., \& Yusuf, S. (2017). DESIGN OF WEBSITE-BASED INFORMATION SYSTEM FOR EDOCUMENT ADMINISTRASI IN THE COMMUNITY SERVICE UNIT (A Case Study at Rajabasa District). INTERNATIONAL JOURNAL OF COMPUTERS \& TECHNOLOGY, 16(7), 7010-7020.

Febriani, O. M., \& Wahyuni, T. (2017, October). PERANCANGAN SISTEM E-DOCUMENT ADMINISTRASI LOGBOOK PENELITIAN PADA UNIT LAYANAN DI BANDAR LAMPUNG. In Prosiding Seminar Nasional Darmajaya (Vol. 1, No. 1, pp. 187-194).

Febriani, O. M., \& Permadi, A. B. (2017). Implementasi Sistem Aplikasi Data Bimbingan dan Pelanggaran Siswa pada Sekolah Menengah Atas di Lampung Tengah dengan Metode Analisis dan Desain Sistem Terdistribusi (SSAD). EXPERT, 7(1).

Febriani, O. M., \& Ambarwati, L. (2015). PERANCANGAN APLIKASI PENGOLAHAN DATA PENJUALAN UKM KELANTING KHAS TELO DESA SIDOHARJO KECAMATAN JATI AGUNG KABUPATEN LAMPUNG SELATAN. Jurnal Teknologi Informasi dan Bisnis Pengabdian Masyarakat Darmajaya, 1(1), 77-95.

Febriani, O. M. (2015). Rancang Bangun Aplikasi Ecommercemenggunakan Freewebstore 
$\sum_{\text {QUIZ Selected Section Class }}^{\text {Fakultas Komputer }}$

Arga Ade Audiya

pada UKM Kelanting di Desa

Sidoharjo Lampung Selatan. Prosiding

Sembistek 2014, 1(02), 446-458. 